Abstracta Iranica Abstracta Iranica

Revue bibliographique pour le domaine irano-aryen

Volume 28 | 2007

Comptes rendus des publications de 2005

\title{
Iran's Developing Military Capabilities. Washington, Center for Strategic and International Studies, 2005, 145 p.
}

Anicée Van Engeland

\section{(2) OpenEdition}

1 Journals

Édition électronique

URL : http://journals.openedition.org/abstractairanica/18841

DOI : 10.4000/abstractairanica. 18841

ISSN : 1961-960X

Éditeur :

CNRS (UMR 7528 Mondes iraniens et indiens), Éditions de l'IFRI

\section{Édition imprimée}

Date de publication : 15 mai 2007

ISSN : 0240-8910

Référence électronique

Anicée Van Engeland, «Iran's Developing Military Capabilities. Washington, Center for Strategic and International Studies, 2005, 145 p. », Abstracta Iranica [En ligne], Volume 28 | 2007, document 410, mis en ligne le 18 septembre 2007, consulté le 25 septembre 2020. URL : http://journals.openedition.org/ abstractairanica/18841 ; DOI : https://doi.org/10.4000/abstractairanica.18841

Ce document a été généré automatiquement le 25 septembre 2020.

Tous droits réservés 


\title{
Iran's Developing Military Capabilities. Washington, Center for Strategic and International Studies, 2005,
}

$145 \mathrm{p}$.

\author{
Anicée Van Engeland
}

1 Selon Anthony Cordesman, et ce contrairement à l'image offerte par le régime, l'Iran a des moyens militaires peu modernes par rapport aux temps du Shah ou de la guerre avec l'Irak. Cependant, les gouvernements successifs ont mis l'accent sur le renforcement des forces dites conventionnelles et les armes de longue portée. L'A. fait ainsi une revue complète des armes conventionnelles, de moyens de l'armée, des forces des gardiens de la révolution, l'organisation et la puissance de la force navale et de l'armée de l'air iraniennes et examine la capacité du pays à produire l'arme de destruction massive. L'Iran dispose ainsi de moyens importants pour mener une guerre asymétrique et pose maintenant une menace de nature nouvelle: le nucléaire. Il est évident que l'Iran cherche à développer son matériel et son armement nucléaire. Bien que l'Iran nie avoir développé des armements chimiques et biologiques, cette donnée reste une inconnue. Ce n'est pas la seule inconnue du livre puisque Cordesman ne peut faire un bilan de l'état de la force navale iranienne sur lesquelles il détient peu d'informations; or les capacités opérationnelles de la force navale sont, comme il le souligne, essentielles en cas de guerre dans le golfe Persique; il détient aussi peu d'informations sur la qualité des pilotes de l'air iranien, autre problématique essentielle.

2 L'A. rappelle que les rapports de l'AIEA démontrent uniquement la volonté persistante de la République islamique d'obtenir l'arme nucléaire. Il conclut qu'aujourd'hui l'Iran est la seule puissance régionale capable de poser une menace militaire sérieuse dans le golfe Persique. Ce rapport trouve sa source dans des données officielles et non officielles et c'est ce qui en fait un ouvrage unique et essentiel. L'abondance 
d'informations et de statistiques permettent de dresser un bilan éloquent des moyens militaires en Iran en 2005.

INDEX

Thèmes : 13.1. Iran

AUTEURS

ANICÉE VAN ENGELAND

Paris 